\title{
Opportunities to utilize traditional phenological knowledge to support adaptive management of social-ecological systems vulnerable to changes in climate and fire regimes
}

\author{
Christopher A. Armatas $^{1}, \underline{\text { Tyron J. Venn }}^{1,2}$, Brooke B. McBride $^{1}$, Alan E. Watson $^{3}$ and Steve J. Carver $^{4}$
}

\begin{abstract}
The field of adaptive management has been embraced by researchers and managers in the United States as an approach to improve natural resource stewardship in the face of uncertainty and complex environmental problems. Integrating multiple knowledge sources and feedback mechanisms is an important step in this approach. Our objective is to contribute to the limited literature that describes the benefits of better integrating indigenous knowledge(IK) with other sources of knowledge in making adaptive-management decisions. Specifically, we advocate the integration of traditional phenological knowledge (TPK), a subset of IK, and highlight opportunities for this knowledge to support policy and practice of adaptive management with reference to policy and practice of adapting to uncharacteristic fire regimes and climate change in the western United States.
\end{abstract}

Key Words: climate change adaptation; fire-adapted ecosystems; indigenous fire management; resilience; traditional ecological knowledge; western United States

\section{INTRODUCTION}

There is broad agreement, though not consensus, that fire regimes in dry, low-elevation forests in the western United States, which are often dominated by ponderosa pine (Pinus ponderosa), are significantly different from historic fire regimes because human interventions, such as fire suppression and cessation of indigenous burning have replaced frequent, low-severity fires with relatively infrequent fires of greater severity (Keane et al. 2002, Schoennagel et al. 2004, Stephens et al. 2013, Williams 2013). In addition to changed fire regimes, climate change and associated effects, such as increased weather variability, e.g., the occurrence of extreme temperature and precipitation events, and shifting seasonal events, e.g., timing of spring river runoff, have led to a decline in the integrity of many ecosystems in the western United States (Romero-Lankao et al. 2014). Together, these changes pose a threat to the capacity of social-ecological systems (SES) to provide important benefits to humans (Keane et al. 2002, Venn and Calkin 2011, Armatas 2013, Romero-Lankao et al. 2014). For instance, uncharacteristic fire regimes and prolonged drought have increased the danger of catastrophic wildfire on many forests in the western United States, which threatens the ability of those forests to provide important subsistence and recreation benefits, environmental benefits including carbon sequestration, and production benefits such as timber.

In an unpredictable and changing world, the sustainability of SESs faced with a variety of threats, shocks, and stressors hinges, in large part, on the resilience of those systems or, in other words, their ability to adapt to a disturbance without undergoing a radical change in system functionality (Folke et al. 2002a, Berkes and Turner 2006). In the face of uncertainty and complex environmental problems, it has been suggested that adaptive management can bolster the resilience of SESs. Adaptive management emphasizes flexible decision making and responsive institutions, incorporation of various sources of knowledge, and an iterative learning process about how management intervention affects SESs (Berkes et al. 2000, NRC 2004, Stankey et al. 2005, Williams et al. 2009, Allen and Gunderson 2011). Fundamentally, adaptive management "acknowledges that environmental conditions will always change, thus requiring management institutions to respond to feedbacks by adjusting and evolving" (Berkes 2008:72). This acknowledgement is also central to indigenous knowledge (IK) systems, which have been developed through flexible social networks; long-term interaction and respectful, sustainable relationships with the natural world; and iterative processes focused on learning-by-doing. Indigenous knowledge systems, built on experiential knowledge that is not static but constantly evolving can, therefore, potentially bolster resilience of SESs by improving natural resource management, restoration, and conservation, and developing strategies for adapting to modern environmental problems (Berkes et al. 2000, Folke et al. 2002b, Jolly et al. 2002, Berkes and Turner 2006, Senos et al. 2006, Berkes 2009, Berkes and Berkes 2009, Wildcat 2009, Green and Raygorodetsky 2010, Nakashima et al. 2012, Turnhout et al. 2012, Watson et al. 2012, Gómez-Baggethun et al. 2013, Lake 2013, Turner and Spalding 2013, Emery et al. 2014). Although there is some concern that IK may not be as reliable in the face of rapid climate change and increased uncertainty, proponents of IK for improved adaptation and increased resilience of SESs in uncertain times stress that the benefit is derived less from a specific piece of knowledge, and more from the hyperawareness gained through the knowledge-development process, and the inherent worldview that fosters a responsibility to treat the environment more like a relative than resource (Ford et al. 2007, Nakashima et al. 2012, Wildcat 2013).

To our knowledge, this is the first synthesis paper focusing on the potential benefits of a subset of IK, known as traditional phenological knowledge (TPK), for sustaining SESs by informing adaptation to uncharacteristic fire regimes and a changing climate in the western United States. To clearly highlight the potential benefits of TPK for informing adaptation to these two complex environmental stressors, we suggest that it be integrated into the 
broad management framework known as adaptive management. To document the opportunities that could be generated by greater integration of these fields and to promote expansion of the body of knowledge about TPK, we: (1) define adaptive management and TPK; (2) review North American and international literature that describes historic, contemporary, and potential future applications of TPK; and (3) describe opportunities to apply TPK to support adaptive management in the western United States. The conclusion summarizes the benefits of TPK for informing policy and practice aimed at adapting SESs in the face of uncharacteristic fire regimes and climate change.

\section{ADAPTIVE MANAGEMENT AND TRADITIONAL PHENOLOGICAL KNOWLEDGE}

Adaptive management has been embraced by many federal agencies in the United States, including the United States Department of Agriculture - Forest Service, the United States Department of the Interior (USDOI) - Bureau of Land Management, and the United States Agency for International Development, as an approach to improve natural resource stewardship in the face of uncertainty and complex environmental problems (Stankey et al. 2005, USAID 2005, Williams et al. 2009). For example, the USDOI technical guide on adaptive management explicitly states: "adaptive management holds great promise in reducing the uncertainties that limit effective management of natural resource systems" (Williams et al. 2009: v). Adaptive management is more than just simply changing management approaches in the face of failed policies (Murray and Marmorek 2004, Williams et al. 2009). Adaptive management involves identifying the problem, establishing management objectives, exploring alternative strategies to achieve those objectives, predicting the results of alternative strategies, implementing strategies and monitoring the results to understand their efficacy toward the desired outcomes, and, finally, iteratively updating knowledge and management strategies (Kaufmann et al. 2003, Murray and Marmorek 2004).

Although adaptive management is supported as a way to address uncertainty and complex environmental problems, the successful application of its theory into practice is elusive (Susskind et al. 2012, Scarlett 2013, McLoughlin and Thoms 2015). In theory, adaptive management should embrace uncertainty (gaps in knowledge) while striving to build knowledge and challenge the status quo by exploring innovative alternatives that facilitate better understanding of how systems work and react to management (Williams et al. 2009, Fabricius and Cundill 2014). Integral to adaptive management is broad stakeholder involvement and community participation in addition to that of experts and managers, because there is a need for both experiential knowledge and scientifically derived knowledge, stakeholder buyin, reframing of the problem within the constraints of governance systems, and long-term monitoring of the effects of implemented alternative strategies (USAID 2005, McLoughlin and Thoms 2015). Integrating various knowledge sources and different ways of knowing is also important for adaptive management (Stankey et al. 2005). For example, adaptive management can be more effective when incorporating the complementary knowledge systems of western science and IK; however, it is likely that institutional barriers and biases will need to be reflected upon before IK can be successfully integrated (Stankey et al. 2005, Wilcock 2007, Berkes 2008). In practice, adaptive management approaches are often characterized by limited stakeholder participation outside of managers and scientists, a lack of iterative adjustment of the management cycle, i.e., reluctance to depart from traditional management approaches, and a greater focus on learning about governance related challenges than on learning about the effects of decision making on ecosystems (Moore et al. 2011, Rist et al. 2013, Fabricius and Cundill 2014).

There is no consensus regarding use of the term "indigenous" versus "traditional" when describing the place-based knowledge systems of peoples intimately connected to their surrounding environment (Sefa Dei et al. 2000, Houde 2007, Berkes 2008, Rist et al. 2010, Pierotti 2011). As is most common in the literature, we use the term "indigenous knowledge" when referencing the broad range of knowledge held by indigenous people, whereas we use "traditional ecological knowledge" (TEK) and "traditional phenological knowledge" (TPK) when referencing ecological and phenological subsets of IK. Indigenous knowledge encompasses a broad range of knowledge that is unique to a given geography and people (Warren et al. 1995), and not all of it is related to ecology, e.g., ethnoastronomy, (Ceci 1978) or even the natural world, e.g., ethno-finance, (Bray and Els 2007). Even the more narrowly defined TEK includes the extensive body of knowledge related to the "relationship of living beings (including humans) with one another and with their environment" (Berkes 2008:7). Traditional ecological knowledge draws broadly from information related to species identification and classification, e.g., ethnobiology, human understanding of the relationships between ecological processes and the environment, e.g., human ecology, livelihood practices, and norms for peoples' roles within ecosystems, e.g., sustainable resource utilization/management (Berkes 2008).

The compatibility of IK and adaptive management has been discussed (e.g., Berkes et al. 2000, Wilcock 2007, Berkes 2008), but because of their broad natures, recommending the application of IK or TEK to support policies and practices of adaptive management in addressing environmental issues such as uncharacteristic fire regimes and climate change is akin to calling on the totality of western knowledge or, slightly more specifically, all of the social and natural sciences to do the same. However, successful adaptive management will require identifying threats and stressors, and understanding feedbacks, indicators of change, and triggers for action. Traditional phenological knowledge is especially useful in this regard.

The emergence of the study of TPK parallels that of a branch of ecological science known as phenology. Phenology is the study of recurring plant, fungi, and animal life cycle stages, especially as they relate to climate and weather (Schwartz 2013). Phenological processes such as developmental stages of plant, fungi, and animal species triggered by accumulated heat, or exceedance of temperature thresholds, can also serve as indicators of seasonal variation and proxies to monitor the biological effect of climate change (Larcher 1983, Rathcke and Lacey 1985, Lantz and Turner 2003). Lantz and Turner (2003:265) introduced and defined the term, TPK, to encompass IK regarding phenology:

All knowledge of biological seasonality, including the observation of life cycle changes in specific plant or animal species to indicate the timing of the onset of 
growth stages in other species, linguistic references to phenological events, traditional conceptions of time as they relate to seasonal change, and spiritual beliefs about cause and effect relationships of seasonal change.

Traditional phenological knowledge encompasses both "norms and baselines for seasonal events" and a "range of variation in species abundance and productivity" (Turner and Clifton 2009:185), which may serve as a benchmark from which change in phenological events can be measured (Nabhan 2010). The biological aspect is important for distinguishing phenology from the related term of "seasonality," which focuses on nonbiological events such as the spring break-up of ice on fresh water lakes (Schwartz 2013). Lantz and Turner (2003) separated TPK into categories of direct and indirect knowledge. Indeed, direct TPK refers to the observation of phenological changes in indicator species to signal the seasonal timing of secondary species. For example, among the Karuk, Hupa, and Yurok tribes of the western Klamath Mountains of northwestern California, the dogwood (Cornus nuttalli) flowers, also known as bracks, signal the arrival of sturgeon (Acipenser medirostris), lamprey eels (Lampetra similis), and spring Chinook salmon (Oncorhynchus tshawytscha) to the midupper reaches of the Klamath-Trinity River system. Using the dogwood flowering "seasonal calendar" as the indicator for the time to fish, allowed tribal fishermen greater prediction of fish migration at favored fishing sites and increased efficiency with different harvesting methods. In addition, the Karuk use the song of the common-black cricket during the late spring evenings as an indicator at a particular waterfall for increased opportunity for gafting lamprey eels off the rocks (F. Lake, personal communication). Indirect TPK is drawn from broad indigenous knowledge and includes knowledge that is embedded in language, beliefs, myths, rituals, and ceremonies that relate to the seasonal round and conceptions of time and the seasons (Lantz and Turner 2003). For example, the Hidatsa tribe of the western United States would plant sunflower seeds during "Mapiá-ócë-mídi," which translates to "sunflowerplanting-moon," and most closely aligns with April and the time when ice would break up on the Missouri River (Wilson 1987:16).

Direct and indirect TPK are not necessarily mutually exclusive. For example, in areas of British Columbia, there is the belief that the breeding call of the Swainson's thrush (Catharus ustulatus) facilitates the ripening of the salmonberry (Rubus spectabilis), because the timing of both events typically coincide (Campbell et al. 1997, Lantz and Turner 2003). Indeed, the meaning of the indigenous names given to the Swainson's thrush across several languages is "the salmonberry bird" (Lantz and Turner 2003). Direct TPK is evident by the use of the breeding call as an indicator for the ripening of the salmonberry, and indirect TPK is evident in the belief that there is a causal relationship between the breeding call and the ripening of the salmonberry.

Figure 1 illustrates a conceptualization of how IK and the subsets of ecological, phenological, and seasonal knowledge are related. Within the larger body of IK, TPK draws on both ecological and seasonal knowledges and offers promise for society's current struggles to strategically plan for climate change adaptation. Of particular interest in the western United States are the ways in which TPK and previously documented adaptations have addressed problems in maintaining culturally significant fireadapted ecosystems.
Fig. 1. The relationship between indigenous knowledge and its subsets.

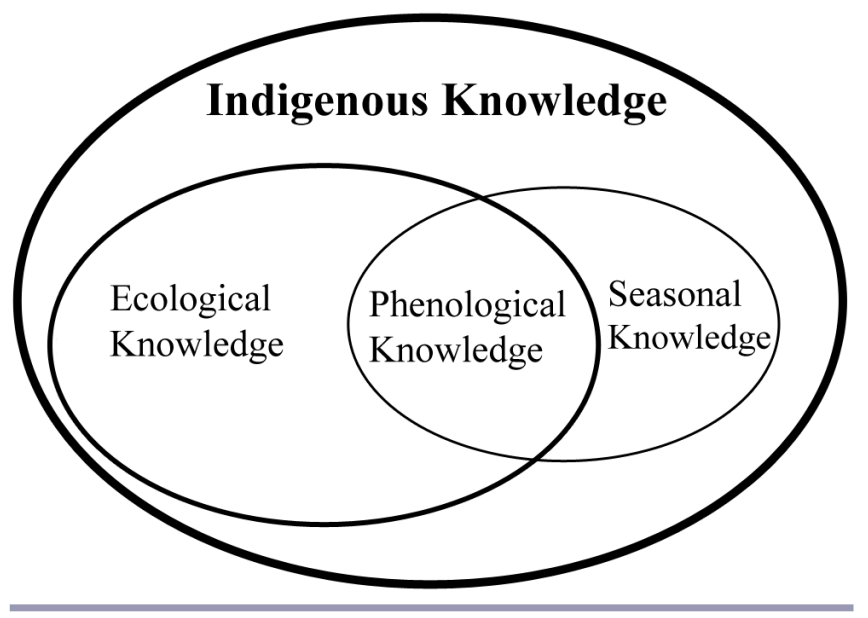

\section{HISTORIC AND POTENTIAL APPLICATIONS OF TRADITIONAL PHENOLOGICAL KNOWLEDGE TO MANAGE AND ADAPT TO UNCHARACTERISTIC FIRE REGIMES AND CLIMATE CHANGE}

Historically, TPK often facilitated every day practices important to culture and survival, such as hunting and gathering, agriculture, traditional burning practices, and forecasting of weather and natural disasters. These practices provided a myriad of benefits including: food security; safety from wildlife; increased abundance of, and improved access to, flora, fungi, and fauna; protection from floods and fire; and cultural identity. More recently, TPK has been applied by both indigenous and nonindigenous peoples to understand the impacts of a changing climate on SESs. Observing the impacts of climate change acknowledges environmental change and facilitates understanding of how that change affects cultural landscapes and values. This is also an important step in adaptive management, because clearly understanding the current state of the SES provides the baseline from which to monitor the success of adaptive strategies.

Traditional phenological knowledge (TPK) and fire management Understanding the historic range of variability, or reference conditions, of forests is an important aspect of contemporary fire and natural resource management practices in the western United States, which focuses on restoring ecosystems, historic fire regimes, and fuel structures (Fulé et al. 1997, Laughlin et al. 2004, Stephens and Ruth 2005, Shinneman et al. 2008, Keith et al. 2010). Contemporary forest conditions of dry, lower elevation forests in the western United States, which are often dominated by ponderosa pine, are characterized by higher fuel loads and tree densities, and lower levels of biodiversity and fire-resistant trees than prior to European settlement because of land management changes, such as fire suppression and exclusion (Fulé et al. 1997, Allen et al. 2002, Shinneman et al. 2008, Rocca et al. 2014). As a result, the resilience of SESs is threatened by increasing fire hazards and further loss of biodiversity (Kimmerer 2000, Allen et al. 2002). Restoring forest health via proactive fire management strategies, such as prescribed fire and mechanical thinning has been recommended (Agee 2002); however, such efforts are often 
complicated by concerns including costs, losing control of prescribed fires, degraded landscape aesthetics, and potential deleterious effects on threatened or endangered species (Winter et al. 2002, Brunson and Shindler 2004, Stephens and Ruth 2005, Stetler et al. 2010).

Indigenous peoples have long used intentional fire on the landscape, commonly referred to as traditional burning practices, for a number of reasons: clearing meadows of thick brush and trees to create better forage for wildlife and facilitate the growth of important plants for subsistence; improving settlement areas, campsites, and trails; pest management; crop management; and the removal of aged and diseased forest for both enhancement of habitat for plants and animals, and reduction of fuels for mitigation of catastrophic fire (Lewis 1982, Johnson Gottesfeld 1994, Anderson 1999, Stewart 2002, Williams 2003, Karuk Tribe 2009, Carroll et al. 2010, Christianson et al. 2012, Huffman 2013, Lake 2013). In the context of addressing uncharacteristic fire regimes in the western United States, TPK can provide placespecific information to inform holistic adaptive management strategies that: (1) cautiously apply fire to the landscape to reduce fuels and mitigate the risk of catastrophic wildfire to people and their environment; (2) enhance conservation and restoration of fire-dependent natural resource values; and (3) account for ecological reference conditions to support efforts to attain preEuropean settlement fire regimes through proactive fire management and, as a result, enhance biodiversity conservation.

There are several historic examples in which TPK has been applied in the United States to dictate safe times to burn to avoid losing control of fire (French 1999, Turner 1999, White 1999); however, a particularly detailed example was provided by Lewis (1989) for Aboriginal peoples in the Arnhem Land region of Australia. Traditionally, the majority of dry-season burns in Arnhem Land were begun with the first flowering of the "andjalen" (Eucalyptus miniata) when, because of relatively moist conditions, fires would burn only for a couple of hours. In addition to the relative safety of burning during this time, there were several added benefits for burning in this seasonal window, including reduction of fuels ahead of the dry season, promotion of prized species (e.g., water chestnut, Eleocharis dulcis), and facilitation of kangaroo hunting (Russel-Smith et al. 1997). To avoid potentially devastating fires, which could burn all day and night, burning typically ceased before the beginning of the hot-dry season known as "garrung" which is marked by the final flowering of "anrebel" (Eucalyptus tetrodonta) and andjalen (Russel-Smith et al. 1997).

Traditional phenological knowledge regarding the effects of fire on the phenological phases of specific plant and animal species has been incorporated into traditional burning practices to conserve and restore important cultural and subsistence benefits. Examples from the western United States and Alaska include improvement of habitat for wildlife forage (Kimmerer and Lake 2001), facilitation of plant development ideal for craft making, foraging for subsistence, attracting important game species, and harvesting crops (Anderson 1996, 1999, Boyd 1999, French 1999, Turner 1999, White 1999, Natcher et al. 2007). According to Kimmerer and Lake (2001), indigenous peoples in the southwest United States burned particular shrublands in the fall to increase forage for deer, because they knew that increased soil moisture would support resprouting and, thus, attract deer in the winter.
Conversely, it was also understood in this area that burning shrublands in the spring was best for tobacco cultivation, because the increased fire intensity would impede resprouting, and the land would be suitable for planting. Anderson (1996) discussed how indigenous peoples in California used fire and their knowledge of deer grass (Muhlenbergia rigens) development and phenology to maintain a healthy population of the latter for basket-weaving. Senos et al. (2006) highlighted several ongoing ecological and cultural restoration efforts in the western United States and Canada in which TPK is integral. For example, the Songhees Nation of southern Vancouver Island started a restoration program that will reintroduce regular burning practices to reclaim important cultural and subsistence values such as the Songhees tradition of tending camas (Camassia sp.), plants in the asparagus family.

Traditional phenological knowledge related to fire has been used in the past and could be used today to enhance biodiversity at scales from landscape to individual populations, which is important for improving resilience of SESs (Holling and Meffe 1996). According to Peacock and Turner (2000), traditional burning practices were the most common technique used by indigenous peoples to manage biodiversity at a community scale, which is a spatial scale encompassing individual populations lying within the landscape scale. Norton et al. (1999) discussed ethnohistorical evidence, which suggests that prairies of western Washington and Oregon have largely disappeared in the last 130 years, in large part because of a cessation of indigenous burning. It was noted that indigenous peoples would frequently burn the prairies to kill fast-growing trees and maintain open grassy areas, because it was known that desirable species such as oak (Quercus garryana), huckleberries, and other berries are shade intolerant. In a study of over 50 riparian plant species in central California, in which riparian ecosystems are relatively rare, Hankins (2013) found that prescribed fire, similar to indigenous burning, can maintain species abundance and habitat diversity at a community scale.

\section{Traditional phenological knowledge (TPK) and climate change}

Climate change has and is expected to continue to affect SESs in the western United States in a variety of ways, including poleward shifts in ranges of plant and animal species, changes in the timing of bird migration, early spring onset, longer growing seasons, and increases in extreme precipitation and temperature events (Kunkel et al. 1999, Cayan et al. 2001, DeGaetano and Allen 2002, Easterling 2002, Walther et al. 2002, Feng and Hu 2004, RomeroLankao et al. 2014). Such changes increase the vulnerability of important livelihood practices such as agriculture, hunting, and gathering. Traditional phenological knowledge can contribute to adaptive management strategies that improve resilience of SESs in the face of climate change by providing indicators to identify and assess environmental change and by highlighting potential adaptation strategies to sustain important livelihood practices and natural resource values.

Observed climate change impacts on SESs evidenced by application of TPK in North America and elsewhere include: changes in animal migratory patterns, behavior, and populations; different seasonal timing of plant maturation, greening, and fruiting; growth of previously unseen plants; and changes and increased unpredictability of weather and seasonal events 
(Ashord and Castleden 2001, Jolly et al. 2002, Thorpe et al. 2002, Turner and Clifton 2009, Green et al. 2010, Downing and Cuerrier 2011, Herman-Mercer et al. 2011, Egeru 2012). For example, Jolly et al. (2002) documented several observations made by members of Inuvialuit communities in the western Canadian Arctic that were attributed to climate change, such as changes in the timing of caribou (Rangifer tarandus) migrations and smaller populations of ringed seals ( Pusa hispida). Herman-Mercer et al. (2011) interviewed indigenous peoples in Alaska, United States, who noticed, over the course of their lives, a decrease in quantity and quality of salmonberries; a change attributed to a lack of snow and the rapid drying of tundra resulting from quicker snowmelt.

Some studies have discussed how TPK has actually been applied to increase flexibility and the understanding of how SESs respond to climate change and increased variation in seasonal cycles (Jolly et al. 2002, CIER 2008, Ziervogel and Opere 2010, Chinlampianga 2011, Gupta and Singh 2011, Egeru 2012). For example, Turner and Clifton (2009) explained how indigenous peoples in British Columbia, Canada, use the growth of stinging nettles (Urtica dioica) as a proxy to indicate when culturally important seaweed (Porphyra abbottiae) is ready for harvest. This has allowed for adaptation to variability in weather and avoids investment of time, money, and energy in traveling to seaweed sites at an inopportune time.

More commonly, TPK studies indicate how adaptation to climate change could potentially be facilitated by seasonal calendars, sometimes referred to as seasonal rounds, seasonal narratives, or Aboriginal ecological calendars (Green et al. 2010, Downing and Cuerrier 2011, Lefale 2011, Prober et al. 2011, Woodward et al. 2012, Leonard et al. 2013, Turpin et al. 2013). These calendars, unlike the commonly used Gregorian (western) calendar in which dates and seasons are fixed, are composed of flexible seasons that are often separated by weather and climate events that correlate with particular biological indicators. In other words, they are calendars dictated by phenological events that have been observed by indigenous peoples for generations. Hunn (1990) presented the seasonal round of the Native American people of the midColumbia River Basin in the northwest United States, which has seasons delineated by TPK. The start of the spring season, known as "wawáxam" is signaled by the arrival of Chinook salmon.

Seasonal calendars can help to guide important daily and yearly activities in the face of "year-by-year variations in seasonal cycles" (Turner and Clifton 2009:185). For example, in the context of subsistence practices, Ruelle and Kassam (2011:304) have noted that the diversity of TPK held by elders of the Standing Rock Nation in western United States could help to anticipate the availability of food plants regardless of the Gregorian calendar date, and "therefore help communities anticipate new climate variability." For instance, the release of cottonwood (Populus sp.) seeds along the river is an indication to some elders that the prairie turnip (Psoralea esculenta) is ready for harvest. McNeeley and Shulski (2011) explained how indigenous peoples in Alaska could use TPK to adopt alternative hunting strategies and remain flexible to a shift in the prime hunting time for moose (Alces alces). According to local hunters, in recent years, ideal hunting time has shifted later by two-four weeks because persistent warm weather in late summer and early fall has postponed the mating season of the moose, as a result of bulls limiting their daytime movement in search of cows. This case illustrates the potential for mismatch between adaptation strategies grounded in TPK and management structures based on the Gregorian calendar. Traditional phenological knowledge about mating behavior of moose as it correlates with weather cannot be put into practice legally to ensure a successful and economically efficient harvest because it does not coincide with dates set a year or more in advance. As a result, hunters must implement costly and difficult adjustments, e.g., hunting at night or traveling further, to harvest moose prior to the close of the hunting season. Another potential cost of hunting during warmer times is the risk of meat spoilage (McNeeley and Shulski 2011).

For much of its history, the field of phenology was applied exclusively to agriculture (Schwartz 2013). It is therefore not surprising that research discussing TPK for potential adaptation to climate change is commonly in reference to agriculture. Much of the TPK used for agricultural purposes is indirect, in which the behavior of an indicator species is used to predict the weather and changing of the seasons. This type of TPK may be especially helpful for developing alternative adaptive strategies for addressing the changes to SESs as a result of climate change and increased weather variability. The prediction of weather supported by TPK can guide planting and harvesting (Acharya 2011a, b, Pareek and Trivedi 2011), and the collection of rain for future irrigation (Irfanullah and Motaleb 2011). For example, Acharya (2011a) documented how particular indigenous peoples in India apply TPK regarding the blooming patterns of the nightflowering jasmine (Nyctanthes arbor-tristis) for rainfall prediction to facilitate agriculture. Acharya (2011a) compared the rainfall prediction capacity of TPK to modern forecasting techniques and found that TPK was reliable. Nuanced understanding of how different weather and climate conditions impact the stages of growth of particular crops has also aided adaptation in the agricultural sector. For example, Balemie (2011) documented how TPK has supported adaptation of agricultural practices of Ethiopian farmers to climate change, through informing when to plant and which crop varieties to plant to increase resilience in the face of drought, pests, and diseases. Additionally, TPK may aid agricultural practices by improving understanding of potential mismatches between the flowering of food crops and the pollinators that serve them (Nabhan 2013). Understanding the response of individual species to climate change requires intimate knowledge of specific places and environments, which is provided by TPK that is developed over generations of sustained relationships with a particular landscape.

\section{APPLYING TRADITIONAL PHENOLOGICAL KNOWLEDGE (TPK) FOR ADAPTIVE MANAGEMENT}

Although challenging, dialogue between scientists and indigenous peoples has led to the coproduction of knowledge for a variety of improvements to natural resource management, biodiversity conservation, and climate change adaptation (Berkes 2009). Better integration of TPK with the science of adaptive management will inform holistic and sustainable adaptive management strategies. Specifically, TPK can support the definition of management objectives and inform the development, implementation, and monitoring of alternative resource management strategies. Opportunities for applying TPK to support policy and practice of adaptive management in the western United States include: 
- protection of important human values through a better understanding of both the potential benefits of proactive fire management and the safest times to apply prescribed burns;

- complement fire management and restoration efforts through better understanding of ecological reference conditions and the use of fire to conserve biological diversity;

- enhanced resilience of important livelihood practices, i.e., agriculture, hunting, and gathering, in the face of climate change; and

- compliance with the United States Government's Trust responsibility to tribes and indigenous peoples.

Integrating IK related to fire into current fire management is challenging (Raish et al. 2005). However, the shift made in Australia, in which indigenous peoples and their knowledge have been incorporated into some fire management programs (Lewis 1989, Russell-Smith et al. 1997), could serve as a model. According to Ray et al. (2012:11), such a shift in fire management is not only a demonstration of good ethics, but it can "add finescale local details and historical context, detect changes yet undocumented in scientific studies, and indicate which regional studies apply to a given locale." Greater integration of indigenous peoples into fire management may be particularly feasible in North America because, according to Lewis and Ferguson (1999), even though the ecosystems and cultures of indigenous peoples of Australia are quite different from those of North America, the way in which fire was applied to manage the landscape was quite similar.

Stephens and Ruth (2005) asserted that collaborative stewardship with regard to fire and fuels management should focus, in part, on the equitable distribution of costs and benefits associated with restoration. The potential costs of proactive fire management, e.g., temporarily reduced aesthetics and loss of control of prescribed fire, are well-known and contribute to public opposition but, according to Laughlin et al. (2004), the benefits of low-severity fire are not as well-known. Considering that fire management is one of the most politically charged natural resource issues in the United States (Stetler et al. 2010), garnering support for proactive fire management may require identification and promotion of potential benefits. Traditional phenological knowledge can help develop management objectives regarding proactive fire management of SESs, such as protection of important cultural and subsistence values, and ecological restoration. According to Kimmerer and Lake (2001:39), "seasonality of burning [in the United States] varied with the tribe and ecosystem in question, but in general fire was applied at a carefully considered time that would minimize its destructive nature while harnessing its creative power." Traditional phenological knowledge can also assist in the implementation of alternative management strategies, for example, highlighting the safest times for prescribed burns in the face of unpredictable weather and seasonal changes while also achieving other objectives such as promoting habitat for wildlife.

With regard to fire management for biodiversity conservation, Driscoll et al. (2010) concluded that there is a need for better understanding of animal life cycles, and their movements and habitat needs, as well as species' ability to persist within a locale under different fire regimes. The focus of TPK on species' life cycles and the accumulation and application of knowledge over hundreds to thousands of years suggests that TPK could be especially helpful for predicting the results of alternative firemanagement strategies aimed at ecological restoration. Also, because the benefits of applying fire to the landscape as indigenous peoples once did include conservation of plant species and diversity of landscapes, TPK could assist in the development of alternative strategies aimed at restoration based on improved understanding of the historical ecology of SESs. With a focus on biological seasonality, TPK does not refer specifically to the longterm changes in landscape structure, such as the absence of host plants that support butterfly breeding as a result of fire suppression and exclusion (Baum and Sharber 2012). These changes in landscape structure can interrupt phenological events, as shown by Baum and Sharber (2012) in a study on the breeding habits of monarch butterflies (Danaus plexippus). Thus, TPK can help to highlight changes in landscape structure that result from climate change or fire exclusion and suppression over an extended period of time.

In the context of climate change, TPK can enhance resilience of SESs through informing efficient use of resources by, for example, indicating the best time to hunt or the most drought-resistant crop to sow. Perhaps the most significant contribution of TPK with regard to managing natural resources is the flexibility that it offers in the face of shifting seasonal events. Seasonal rounds, relied upon by many indigenous peoples, can be used to shift away from rigid Gregorian calendars that are increasingly asynchronous with the ecologically appropriate time to perform management activities, such as hunting and gathering.

Realizing the benefits of incorporating TPK into adaptive management will require overcoming several challenges. Possibly the largest challenge is broadly related to adaptive management. Although adaptive management is highly regarded as an approach to address complex environmental problems, such as climate change and uncharacteristic fire regimes, it has seen limited success in practice. A range of issues have impeded the successful application of adaptive management, including institutional and legal barriers that lead to risk-averse management; inadequate collaboration between scientists, stakeholders, and managers; and a lack of funding and time (Greig et al. 2013, Scarlett 2013). In the context of prescribed fire practices, substantive incorporation of TPK into adaptive management may first require greater flexibility within prescribed fire programs, which are required to follow strict guidelines, e.g., fuel moisture content. Perhaps more realistically, TPK could help to affirm or highlight potential deficiencies in current management approaches. However, if this is to be the role of TPK, then it is important that collaborators contributing TPK are fully informed about the extent that their involvement will actually contribute to decision making.

Another challenge is extracting TPK from existing literature. Traditional phenological knowledge is a relatively new term and alternative terms, such as presage biology (Acharya 2011b), indigenous knowledge-based forecasts (Ziervogel and Opere 2010), and ethnophenology (Nabhan 2010) are also used. Another challenge is that scholarly publications about TPK are relatively 
uncommon. For example, in a review of published ethnobotanical literature about indigenous peoples in British Columbia, Canada, Lantz and Turner (2003) summarized findings from several studies but found evidence of TPK sparse. However, they posited that the lack of TPK in these cases was most likely caused by the use of "analytical categories focusing primarily on utilitarian aspects of cultural knowledge" (Lantz and Turner 2003:281), as opposed to a lack of significance assigned to such knowledge by the indigenous peoples being discussed. Additionally, TPK may be deeply embedded in indigenous stories and myths (e.g., Kroeber 1976, Ramsey 1977, Kroeber and Gifford 1980), or studies of IK or TEK. For instance, Agnihotri and Si (2012) contributed to the field of ethno-ornithology with their monograph focused on the nuance of bird nomenclature and classification of the Solega in southern India. Careful reading of the paper reveals a significant amount of TPK.

Overcoming the challenge of sparsely reported and contextspecific TPK will likely require long-term collaboration between researchers and local indigenous communities. In addition, the potential for applying TPK about fire for biodiversity conservation may be greatest in the western United States, where large parcels of public lands encompass traditional homelands and commonly abut current Native American trust lands. According to Driscoll et al. (2010), the traditional methods of applying fire to the landscape may provide the greatest biodiversity benefits on large, intact environments, as opposed to developed, fragmented, or modified landscapes. Resuming traditional burning practices in fragmented or modified landscapes in which land tenure is diverse may not be possible, because of issues related to liability in the event of a prescribed fire causing damage to private property. Carroll et al. (2010) found that, despite the interest of resuming traditional burning practices, Nez Perce tribal members were concerned about the spread of fire to adjacent properties.

Documentation and application of TPK could help to foster unique relationships between United States and tribal governments, which are required by law. As per Executive Order 13175: Consultation and Coordination with Indian Tribal Governments, it is required that agencies, e.g., federal land management agencies, engage American Indian and Alaska Native peoples in government-to-government consultation for any policy that has tribal implications. This requirement goes beyond listening sessions or invitations to public meetings and comment periods. In addition, Executive Order 13653: Preparing the United States for the Impacts of Climate Change, and United States Department of the Interior-Secretarial Order 3285 on Renewable Energy Development calls for collaboration with tribes on preparation and adaptation to climate change. However, the imperative of building relationships with indigenous communities should not be underestimated. An in-depth discussion of the difficulties and recommended approaches for collaborative research with indigenous peoples is beyond the scope of this review (see Smith 1999 and Sillitoe et al. 2002 for excellent discussions). We note, however, that among the challenges of building a research relationship with indigenous peoples is the fact that the term "research" is, according to Smith (1999), a reminder to many indigenous peoples of colonial excesses including the exploitation, extraction, and assumed ownership of knowledge. Sillitoe (2002) argued that, although praiseworthy, attempting to overcome this intellectual imperialism by blurring the lines between the two intellectual traditions (i.e., western science and IK) is unrealistic. Indeed, the two intellectual traditions are predicated upon different epistemologies and ontologies and, consequently, there is potential for conflicting knowledge. In other words, when beliefs about how knowledge is created and what constitutes truth are fundamentally different, then deciding, for example, the best time to initiate a prescribed burn may result in irreconcilable differences. However, the loss of potentially productive collaborative relationships need not be the result.

It has been argued that research collaboratives may be best served by embracing the strengths and weaknesses of each intellectual tradition to create a synergy between them (Sillitoe 2002). In the context of fire management, Sletto and Rodriguez (2013:164) discuss intercultural fire management as a way to address an ongoing conflict between state-run fire management and indigenous fire management in Venezuela, which requires the creation of opportunities for "reflection and public deliberation about fire management as perceived by different disciplines and knowledge systems." The challenge of incorporating IK into adaptive management is likely compounded by language such as "best available science," which fosters a competitive spirit that can be both beneficial and detrimental. Successful integration of IK into adaptive management will require open minds, tempering egos, and patience. Further, according to Berkes (2009:153), collaborative research with indigenous peoples is " always preceded by trust-building, development of working relationships, and respect for areas that should not be researched."

\section{CONCLUSION}

Indigenous peoples have a wealth of place-based traditional phenological knowledge (TPK) that is based on empirical observations gathered over hundreds to thousands of years, and intervention in the environment that is grounded in norms of respect and reciprocity. This knowledge has been invaluable to indigenous communities living with and adapting to natural variation in ecological disturbances and climate. Today, humanity must adapt to a world in which social-ecological systems are threatened by accelerating changes in the environment. We argue that contemporary efforts toward adaptive management of natural systems threatened by these changes can be supported by awareness and application of TPK. The review of TPK literature related to fire management and climate, two of the most important environmental stressors in the western United States, revealed several potential opportunities to apply TPK to support adaptive management of SESs. Better integration of the bodies of science and knowledge pertaining to adaptive management and TPK is likely to suggest innovative policies and practices to improve the resilience and adaptive capacity of SESs to human-caused changes in the environment.

The feasibility and effectiveness of applying TPK for adaptation to uncharacteristic fire regimes and climate change appear high in the western United States, where abundant public land encompasses traditional Native American homelands, and is often in close proximity to current reservations. The process of developing a deeper understanding of TPK and its potential applications in the western United States can help communities, both tribal and nontribal, and conservation agencies build 
relationships. Through these relationships, it may be possible to prepare future fire and forest management plans, and climate change adaptation strategies that are culturally relevant and capable of building more resilient SESs. Beyond the collaborative process of understanding TPK, the knowledge itself is particularly salient for adaptive management in the face of uncharacteristic fire regimes and climate change, because it can facilitate: (1) implementation of proactive fire management strategies such as prescribed burns; (2) restoration efforts through better understanding of reference conditions and environmental response; (3) identification of culturally significant natural resource values that can be protected, restored, and sustained by methods such as prescribed fire and mechanical treatments, thus, garnering support for proactive fire management; and (4) protection of important livelihood practices such as agriculture and hunting and gathering.

Responses to this article can be read online at: http://www.ecologyandsociety.org/issues/responses. $\mathrm{php} / 7905$

\section{Acknowledgments:}

This project is jointly supported by the Joint Fire Sciences Program (\#12-2-01-18), the Rocky Mountain Research Station - Aldo Leopold Wilderness Research Institute, and the University of Montana. We thank Frank Lake and Marla Emery of the United States Forest Service for commenting on an earlier draft of this paper. The opinions, conclusions, and recommendations expressed in this paper are those of the authors.

\section{LITERATURE CITED}

Acharya, S. 2011a. Prediction of rainfall variation through flowering phenology of night-flowering jasmine (Nyctanthes arbor-tristis L.; Verbenaceae) in Tripura. Indian Journal of Traditional Knowledge 10(1):96-101.

Acharya, S. 2011b. Presage biology: lessons from nature in weather forecasting. Indian Journal of Traditional Knowledge 10 (1):114-124.

Agee, J. K. 2002. The fallacy of passive management: managing for fire safe forest reserves. Conservation in Practice 3(1):18-26. http://dx.doi.org/10.1111/j.1526-4629.2002.tb00023.x

Agnihotri, S., and A. Si. 2012. Solega ethno-ornithology. Journal of Ethnobiology 32(2):185-211. http://dx.doi.org/10.2993/0278-0771-32.2.185

Allen, C. R., and L. H. Gunderson. 2011. Pathology and failure in the design and implementation of adaptive management. Journal of Environmental Management 92:1379-1384. http://dx. doi.org/10.1016/j.jenvman.2010.10.063

Allen, C. D., M. Savage, D. A. Falk, K. F. Suckling, T. W. Swetnam, T. Schulke, P. B. Stacey, P. Morgan, M. Hoffman, and J. T. Klingel. 2002. Ecological restoration of southwestern ponderosa pine ecosystems: a broad perspective. Ecological Applications 12(5):1418-1433. http://dx.doi.org/10.1890/1051-0761 (2002)012[1418:erospp]2.0.co;2
Anderson, M. K. 1996. The ethnobotany of deergrass, Muhlenbergia rigens (Poaceae): its uses and fire management by California Indians. Economic Botany 50(4):409-422. http://dx. doi.org/10.1007/bf02866523

Anderson, M. K. 1999. The fire, pruning, and coppice management of temperate ecosystems for basketry material by California Indian tribes. Human Ecology 27(1):79-113. http://dx. doi.org/10.1023/A:1018757317568

Armatas, C. A. 2013. The importance of water-based ecosystem services derived from the Shoshone National Forest. Thesis. University of Montana, Missoula, Montana, USA. [online] URL: http://scholarworks.umt.edu/etd/1025/

Ashford, G., and J. Castleden. 2001. Inuit observations on climate change: final report. International Institute for Sustainable Development, Sachs Harbour, Northwest Territories, Canada. [online] URL: https://www.iisd.org/pdf/inuit final report.pdf

Balemie, K. 2011. Management and uses of farmers' varieties in southwest Ethiopia: a climate change perspective. Indian Journal of Traditional Knowledge 10(1):133-145.

Baum, K. A., and W. V. Sharber. 2012. Fire creates host plant patches for monarch butterflies. Biology Letters 8:968-971. http:// dx.doi.org/10.1098/rsbl.2012.0550

Berkes, F. 2008. Sacred ecology: traditional ecological knowledge and resource management. Second Edition. Taylor and Francis, Philadelphia, Pensylvannia, USA.

Berkes, F. 2009. Indigenous ways of knowing and the study of environmental change. Journal of the Royal Society of New Zealand 34(9):151-156. http://dx.doi.org/10.1080/03014220909510568

Berkes, F., and M. K. Berkes. 2009. Ecological complexity, fuzzy logic, and holism in indigenous knowledge. Futures 41:6-12. http://dx.doi.org/10.1016/j.futures.2008.07.003

Berkes, F., J. Colding, and C. Folke. 2000. Rediscovery of traditional ecological knowledge as adaptive management. Ecological Applications 10(5):1251-1262. http://dx.doi. org/10.1890/1051-0761(2000)010[1251:roteka]2.0.co;2

Berkes, F., J., and N. J. Turner. 2006. Knowledge, learning, and the evolution of conservation practice for social-ecological system resilience. Human Ecology 34(4):479-494. http://dx.doi. org/10.1007/s10745-006-9008-2

Boyd, R. 1999. Introduction. Pages 1-30 in R. Boyd, editor. Indians, fire and the land in the Pacific Northwest. Oregon State University Press, Corvallis, Oegon, USA.

Bray, R. J. C., and G. Els. 2007. Unpacking 'ethno-finance': an introduction to indigenous 'financial' knowledge systems. South African Journal of Information Management 9(1):10. [online] URL: http://www.sajim.co.za/index.php/SAJIM/article/view/15 http:// dx.doi.org/10.4102/sajim.v9i1.15

Brunson, M. W., and B. A. Shindler. 2004. Geographic variation in social acceptability of wildland fuels management in the western United States. Society and Natural Resources 17 (8):661-678. http://dx.doi.org/10.1080/08941920490480688

Campbell, R. W., N. K. Dawe, I. McTaggart-Cowan, J. M. Cooper, G. W. Kaiser, M. C. E. McNall, and G. E. J. Smith. 1997. 
The birds of British Columbia, volume 3: passerines. University of Vancouver Press, Vancouver, British Columbia, Canada.

Carroll, M. S., P. J. Cohn, T. B. Paveglio, D. R. Drader, and P. J. Jakes. 2010. Fire burners to firefighters: the Nez Perce and fire. Journal of Forestry 108(2):71-76.

Cayan, D. R., M. D. Dettinger, S. A. Kammerdiener, J. M. Caprio, and D. H. Peterson. 2001. Changes in the onset of spring in the western United States. Bulletin of the American Meteorological Society 82(3):399-415. http://dx.doi.org/10.1175/1520-0477(2001) 082<0399: citoos $>2.3 . \mathrm{co}: 2$

Ceci, L. 1978. Watchers of the Pleiades: ethnoastronomy among Native cultivators in northeastern North America. Ethnohistory 25:301-317. http://dx.doi.org/10.2307/481683

Chinlampianga, M. 2011. Traditional knowledge, weather prediction and bioindicators: a case study in Mizoram, northeastern India. Indian Journal of Traditional Knowledge 10 (1):207-211.

Christianson, A., T. K. McGee, L. L'Hirondelle. 2012. How historic and current wildfire experiences in an aboriginal community influence mitigation preferences. International Journal of Wildland Fire 22:527-536. http://dx.doi.org/10.1071/ $\underline{\mathrm{WF} 12041}$

Centre for Indigenous Environmental Resources (CIER). 2008. Climate change and First Nations south of 60: impacts, adaptation, and priorities. Full report. Centre for Indigenous Environmental Resources, Winnipeg, Manitoba, Canada. [online] URL: http:// www.yourcier.org/climate-change-and-first-nations-south-of-60impacts-adaptation-and-priorities-2007.html

DeGaetano, A. T., and R. J. Allen. 2002. Trends in twentiethcentury temperature extremes across the United States. Journal of Climate 15(22):3188-3205. http://dx.doi.org/10.1175/1520-0442 (2002)015<3188:titcte>2.0.co:2

Downing, A., and A. Cuerrier. 2011. A synthesis of the impacts of climate change on the First Nations and Inuit of Canada. Indian Journal of Traditional Knowledge 10(1):57-70.

Driscoll, D. A., D. B. Lindenmayer, A. F. Bennett, M. Bode, R. A. Bradstock, G. J. Cary, M. F. Clarke, N. Dexter, R. Fensham, G. Friend, M. Gill, S. James, G. Kay, D. A. Keith, C. MacGregor, J. Russell-Smith, D. Salt, J. E. M. Watson, R. J. Williams, and A. York. 2010. Fire management for biodiversity conservation: key research questions and our capacity to answer them. Biological Conservation 143:1928-1939. http://dx.doi.org/10.1016/j. biocon.2010.05.026

Easterling, D. R. 2002. Recent changes in frost days and the frostfree season in the United States. Bulletin of the American Meteorological Society 83(9):1327-1332. http://dx.doi. org/10.1175/1520-0477(2002)083<1327:RCIFDA>2.3.CO;2

Egeru, A. 2012. Role of indigenous knowledge in climate change adaptation: a case study of the Teso sub-region, eastern Uganda. Indian Journal of Traditional Knowledge 11(2):217-224. [online] URL: https://www.google.ca/url?sa=t\&rct=j\&q=\&esrc=s\&source= web\&cd=1\&ved=0ahUKEwiT- H0uYTKAhXG6x4KHbwDCsQFggcMAA\&url $=\mathrm{http} \% 3 \mathrm{~A} \% 2 \mathrm{~F} \% 2 \mathrm{Fsa}$.indiaenvironmentportal. org.in $\% 2$ Ffiles $\% 2$ Ffile $\% 2$ Fclimate $\% 2520$ change $\% 2520$ adaptation. pdf\&usg=AFQjCNE1JziwTpO1EG4uevT2Blg9yuurAA\&cad=rja
Emery, M. R., A. Wrobel, M. H. Hansen, M. Dockry, W. K. Moser, K. J. Stark, and J. H. Gilbert. 2014. Using traditional ecological knowledge as a basis for targeted forest inventories: paper birch (Betula papyrifera) in the US Great Lakes Region. Journal of Forestry 112(2):207-214. http://dx.doi.org/10.5849/ jof.13-023

Fabricius, C., and G. Cundill. 2014. Learning in adaptive management: insights from published practice. Ecology and Society 19(1):29. http://dx.doi.org/10.5751/es-06263-190129

Feng, S., and Q. Hu. 2004. Changes in agro-meteorological indicators in the contiguous United States: 1951-2000. Theoretical and Applied Climatology 78(4):247-264. http://dx.doi.org/10.1007/ s00704-004-0061-8

Folke, C., S. Carpenter, T. Elmqvist, L. Gunderson, C. Holling, B. Walker, J. Bengtsson, F. Berkes, J. Colding, K. Danell, M. Falkenmark, L. Gordon, R. Kasperson, N. Kautsky, A. Kinzig, S. Levin, K. Mäler, F. Moberg, L. Ohlsson, P. Olsson, E. Ostrom, W. Reid, J. Rockström, H. Savenije, and U. Svedin. $2002 b$. Resilience and sustainable development: building adaptive capacity in a world of transformations. Scientific background paper on resilience for the process of the World Summit on Sustainable Development. Environmental Advisory Council to the Swedish Government, Stockholm, Sweden.

Folke, C., J. Colding, and F. Berkes. 2002a. Synthesis: building resilience and adaptive capacity in social-ecological systems. Pages 352-387 in F. Berkes, J. Colding, and C. Folke, editors. Navigating social-ecological systems: building resilience for complexity and change. Cambridge University Press, Cambridge, $\mathrm{UK}$.

Ford, J., T. Pearce, B. Smit, J. Wandel, M. Allurut, K. Shappa, H. Ittusujurat, and K. Qrunnut. 2007. Reducing vulnerability to climate change in the Arctic: the case of Nunavut, Canada. Arctic 60(2):150-166. http://dx.doi.org/10.14430/arctic240

French, D. 1999. Aboriginal control of huckleberry yield in the northwest. Pages 31-35 in R. Boyd, editor. Indians, fire and the land in the Pacific Northwest. Oregon State University Press, Corvallis, Oregon.

Fulé, P. Z., W. W. Covington, and M. M. Moore. 1997. Determining reference conditions for ecosystem management of southwestern ponderosa pine forests. Ecological Applications 7 (3):895-908. http://dx.doi.org/10.1890/1051-0761(1997)007[0895: drcfem]2.0.co;2

Gómez-Baggethun, E., E. Corbera, and V. Reyes-García. 2013. Traditional ecological knowledge and global environmental change: research findings and policy implications. Ecology and Society 18(4):72. http://dx.doi.org/10.5751/es-06288-180472

Green, D., and G. Raygorodetsky. 2010. Indigenous knowledge of a changing climate. Climatic Change 100:239-242. http://dx. doi.org/10.1007/s10584-010-9804-y

Green, D., J. Billy, and A. Tapim. 2010. Indigenous Australians' knowledge of weather and climate. Climatic Change 100:337-354. http://dx.doi.org/10.1007/s10584-010-9803-Z

Greig, L. A., D. R. Marmorek, C. Murray, and D. C. E. Robinson. 2013. Insight into enabling adaptive management. Ecology and Society 18(3):24. http://dx.doi.org/10.5751/es-05686-180324 
Gupta, A. K., and A. Singh. 2011. Traditional intellect in disaster risk mitigation: Indian outlook-Rajasthan and Bundelkhand icons. Indian Journal of Traditional Knowledge 10(1):156-166.

Hankins, D. L. 2013. The effects of indigenous prescribed fire on riparian vegetation in central California. Ecological Processes 2:24. http://dx.doi.org/10.1186/2192-1709-2-24

Herman-Mercer, N., P. F. Schuster, and K. B. Maracle. 2011. Indigenous observations of climate change in the lower Yukon River Basin, Alaska. Human Organization 70(3):244-252. http:// dx.doi.org/10.17730/humo.70.3.v88841235897071m

Holling, C. S., and G. K. Meffe. 1996. Command and control and the pathology of natural resource management. Conservation Biology 10(2):328-337. http://dx.doi.org/10.1046/ j.1523-1739.1996.10020328.x

Houde, N. 2007. The six faces of traditional ecological knowledge: challenges and opportunities for Canadian comanagement arrangements. Ecology and Society 12(2):34. [online] URL: http:// www.ecologyandsociety.org/vol12/iss2/art34/

Huffman, M. R. 2013. The many elements of traditional fire knowledge: synthesis, classification, and aids to cross-cultural problem solving in fire-dependent systems around the world. Ecology and Society 18(4):3. http://dx.doi.org/10.5751/es-05843-180403

Hunn, E. S. 1990. Nch'i-Wána: "the big river" Mid-Columbia Indians and their land. University of Washington Press, Seattle, Washington, USA.

Irfanullah, H. M., and M. A. Motaleb. 2011. Reading nature's mind: disaster management by indigenous peoples of Bangladesh. Indian Journal of Traditional Knowledge 10 (1):80-90.

Johnson Gottesfeld, L. M. 1994. Aboriginal burning for vegetation management in northwest British Columbia. Human Ecology 22(2):171-188. http://dx.doi.org/10.1007/BF02169038

Jolly, D., F. Berkes, J. Castleden, T. Nichols, and the community of Sachs Harbour. 2002. We can't predict the weather like we used to: Inuvialuit observations of climate change, Sachs Harbour, Western Canadian Arctic. Pages 93-126 in I. Krupnick and D. Jolly, editors. The earth is faster now: indigenous observations of Arctic environmental change. Arctic Research Consortium of the United States, Fairbanks, Alaska, USA.

Karuk Tribe. 2009. Eco-cultural resources management plan: an integrated approach to adaptive problem solving, in the interest of managing the restoration of balanced ecological processes utilizing traditional ecological knowledge supported by western science. Department of Natural Resources, Karuk Tribe, Happy Camp, California, USA. [online] URL: http://www.defendruralamerica. $\underline{\text { com/files/Karuk20100615.pdf }}$

Kaufmann, K., A. Shlisky, and B. Kent. 2003. Integrating scientific knowledge into social and economic decisions for ecologically sound fire and restoration management. Proceedings of the $3^{\text {rd }}$ International Wildland Fire Conference, Syndey, Australia. [online] URL: http://www.fire.uni-freiburg.de/summit-2003/3IWFC/Papers/3-IWFC-062-Kaufmann.pdf

Keane, R. E., K. C. Ryan, T. T. Veblen, C. D. Allen, J. Logan, and B. Hawkes. 2002. Cascading effects of fire exclusion in Rocky
Mountain ecosystems: a literature review. General technical Report. RMRS-GTR-91. U.S. Department of Agriculture, Forest Service, Rocky Mountain Research Station, Fort Collins, Colorado, USA. [online] URL: http://www.fs.fed.us/rm/pubs/ rmrs gtr091.pdf

Keith, R. P., T. T. Veblen, T. L. Schoennagel, and R. L. Sherriff. 2010. Understory vegetation indicates historic fire regimes in ponderosa pine-dominated ecosystems in the Colorado Front Range. Journal of Vegetation Science 21:488-499. http://dx.doi. org/10.1111/j.1654-1103.2009.01156.X

Kimmerer, R. W. 2000. Native knowledge and Native ecosystems. Journal of Forestry 98(8):4-9.

Kimmerer, R. W., and F. K. Lake. 2001. The role of indigenous burning in land management. Journal of Forestry 99(11):36-41.

Kroeber, A. L. 1976. Yurok myths. University of California Press, Berkeley, California, USA.

Kroeber, A. L., and E. W. Gifford. 1980. Karok Myths. University of California Press, Berkeley, California, USA.

Kunkel, K. E., K. Andsager, and D. R. Easterling. 1999. Longterm trends of extreme precipitation events over the conterminous United States and Canada. Journal of Climate 12(8):2515-2527. http://dx.doi.org/10.1175/1520-0442(1999)012<2515:1ttiep >2.0.co;2

Lake, F. K. 2013. Trails, fires, and tribulations: tribal resource management and research issues in northern California. Occasion: Interdisciplinary Studies in the Humanities 5:1-22. [online] URL: http://www.fs.fed.us/psw/publications/lake/ psw 2013 lake005.pdf

Lantz, T. C., and N. J. Turner. 2003. Traditional phenological knowledge of Aboriginal peoples in British Columbia. Journal of Ethnobiology 23(2):263-286. [online] URL: http://www.ou.edu/ cas/botany-micro/ben/lantzturner-revised.pdf

Larcher, W. 1983. Physiological plant ecology: ecophysiology and stress physiology of functional groups. Second Edition. SpringerVerlag, Berlin, Germany.

Laughlin, D. C., J. D. Bakker, M. T. Stoddard, M. L. Daniels, J. D. Springer, C. N. Gildar, A. M. Green, and W. W. Covington. 2004. Toward reference conditions: wildfire effects on flora in an old-growth ponderosa pine forest. Forest Ecology and Management 199:137-152. http://dx.doi.org/10.1016/j.foreco.2004.05.034

Lefale, P. F. 2010. Ua 'afa le Aso, stormy weather today: traditional ecological knowledge of weather and climate. The Samoa experience. Climatic Change 100:317-335. http://dx.doi. org/10.1007/s10584-009-9722-Z

Leonard, S., M. Parsons, K. Olawsky, and F. Kofod. 2013. The role of culture and traditional knowledge in climate change adaptation: insights from East Kimberly, Australia. Global Environmental Change 23:623-632. http://dx.doi.org/10.1016/j. gloenvcha.2013.02.012

Lewis, H. T. 1982. A time for Burning. Boreal Institute for Northern Studies, University of Alberta, Edmonton, Alberta, Canada.

Lewis, H. T. 1989. Ecological and technological knowledge of fire: Aborigines versus park rangers in northern Australia. 
American Anthropologist 91(4):940-961. http://dx.doi.org/10.1525/ aa.1989.91.4.02a00080

Lewis, H. T., and T. A. Ferguson. 1999. Yards, corridors, and mosaics: how to burn a boreal forest. Pages 164-184 in R. Boyd, editor. Indians, fire and the land in the Pacific Northwest. Oregon State University Press, Corvallis, Oregon, USA. http://dx.doi. org/10.1007/bf01262026

McLoughlin, C. A., and M. C. Thoms. 2015. Integrative learning for practicing adaptive resource management. Ecology and Society 20(1):34. http://dx.doi.org/10.5751/es-07303-200134

McNeeley, S. M., and M. D. Shulski. 2011. Anatomy of a closing window: vulnerability to changing seasonality in interior Alaska. Global Environmental Change 21:464-473. http://dx.doi. org/10.1016/j.gloenvcha.2011.02.003

Moore, C. T., E. V. Lonsdorf, M. G. Knutson, H. P. Laskowski, and S. K. Lor. 2011. Adaptive management in the U.S. National Wildlife Refuge System: science-management partnerships for conservation delivery. Journal of Environmental Management 92:1395-1402. http://dx.doi.org/10.1016/j.jenvman.2010.10.065

Murray, C., and D. R. Marmorek. 2004. Adaptive management: a science-based approach to managing ecosystems in the face of uncertainty. Pages 1-10 in N. W. P. Munro, T. B. Herman, K. Beazley, and P. Dearden, editors. Making ecosystem-based management work: proceedings of the fifth international conference on science and management of protected areas, Victoria, B.C., May, 2003. Science and Management of Protected Areas Association, Wolfville, Nova Scotia, Canada.

Nabhan, G. P. 2010. Perspectives in ethnobiology: ethnophenology and climate change. Journal of Ethnobiology 30 (1):1-4. http://dx.doi.org/10.2993/0278-0771-30.1.1

Nabhan, G. P. 2013. Growing food in a hotter, drier land: lessons from desert farmers on adapting to climate uncertainty. Chelsea Green, White River Junction, Vermont, USA.

Nakashima, D. J., K. G. McLean, H. Thulstrup, A. RamosCastillo, and J. Rubis. 2012. Weathering uncertainty: traditional knowledge for climate change assessment and adaptation. United National Educational, Scientific and Cultural Organization, Paris, France. [online] URL: http://collections.unu.edu/view/ $\underline{\text { UNU:1511\#viewAttachments }}$

Natcher, D. C., M. Calef, O. Huntington, S. Trainor, H. P. Huntington, L. DeWilde, S. Rupp, and F. S. Chapin, III. 2007. Factors contributing to the cultural and spatial variability of landscape burning by native peoples of interior Alaska. Ecology and Society 12(1):7. [online] URL: http://www.ecologyandsociety. org/vol12/iss1/art7/

National Research Council (NRC). 2004. Adaptive management for water resources project planning. National Academies, Washington, D.C., USA. [online] URL: http://www.nap.edu/ catalog/10972/adaptive-management-for-water-resources-projectplanning

Norton, H. H., R. Boyd, and E. Hunn. 1999. The Klikitat Trail of south-central Washington: a reconstruction of seasonally used resource sites. Pages 65-93 in R. Boyd, editor. Indians, fire and the land in the Pacific Northwest. Oregon State University Press, Corvallis, Oregon, USA.
Pareek, A., and P. Trivedi. 2011. Cultural values and indigenous knowledge of climate change and disaster prediction in Rajasthan, India. Indian Journal of Traditional Knowledge 10 (1):183-189.

Peacock, S. L., and N. J. Turner. 2000. "Just like a garden": traditional resource management and biodiversity conservation on the interior plateau of British Columbia. Pages 133-179 in P. E. Minnis and W. J. Elisens, editors. Biodiversity and Native America. University of Oklahoma Press, Norman, Oklahoma, USA.

Pierotti, R. 2011. Indigenous knowledge, ecology, and evolutionary biology. Routledge, New York, New York, USA.

Prober, S. M., M. H. O’Connor, and F. J. Walsh. 2011. Australian Aboriginal peoples' seasonal knowledge: a potential basis for shared understanding in environmental management. Ecology and Society 16(2):12. [online] URL: http://www.ecologyandsociety. org/vol16/iss2/art12/

Raish, C., A. González-Cabán, and C. J. Condie. 2005. The importance of traditional fire use and management practices for contemporary land managers in the American Southwest. Environmental Hazards 6(2):115-122. http://dx.doi.org/10.1016/j. hazards.2005.10.004

Ramsey, J. 1977. Coyote was going there: Indian literature of the Oregon Country. University of Washington Press, Seattle, Washington, USA.

Rathcke, B., and E. P. Lacey. 1985. Phenological patterns of terrestrial plants. Annual Review of Ecology, Evolution, and Systematics 16:179-214. http://dx.doi.org/10.1146/annurev. es.16.110185.001143

Ray, L. A., C. A. Kolden, and F. S. Chapin, III. 2012. A case for developing place-based fire management strategies from traditional ecological knowledge. Ecology and Society 17(3):37. http://dx.doi.org/10.5751/es-05070-170337

Rist, L., B. M. Campbell, and P. Frost. 2013. Adaptive management: where are we now? Environmental Conservation 40 (1):5-18. http://dx.doi.org/10.1017/S0376892912000240

Rist, L., R. U. Shaanker, E. J. Milner-Gulland, and J. Ghazoul. 2010. The use of traditional ecological knowledge in forest management: an example from India. Ecology and Society 15 (1):3. [online] URL: http://www.ecologyandsociety.org/vol15/ iss1/art3/

Rocca, M. E., P. M. Brown, L. H. MacDonald, and C. M. Carrico. 2014. Climate change impacts on fire regimes and key ecosystem services in Rocky Mountain forests. Forest Ecology and Management 327:290-305. http://dx.doi.org/10.1016/j.foreco.2014.04.005

Romero-Lankao, P., J. B. Smith, D. Davidson, N. Diffenbaugh, P. Kinney, P. Kirshen, P. Kovacs, and L. Villers Ruiz. 2014. North America. Pages 1-88 in Climate change 2014: impacts, adaptation and vulnerability: volume II: regional impacts. Intergovernmental Panel on Climate Change, CITY, COUTNRY... [online] URL: http://ipcc-wg2.gov/AR5/images/uploads/WGIIAR5-Chap26 FGDall. pdf

Ruelle, M. L., and K.-A. S. Kassam. 2011. Diversity of plant knowledge as an adaptive asset: a case study with Standing Rock 
elders. Economic Botany 65(3):295-307. http://dx.doi.org/10.1007/ s12231-011-9168-X

Russell-Smith, J., D. Lucas, M. Gapindi, B. Gunbunuka, N. Kapirigi, G. Namingum, K. Lucas, P. Giuliani, and G. Chaloupka. 1997. Aboriginal resource utilization and fire management practice in western Arnhem Land, monsoonal northern Australia: notes for prehistory, lessons for the future. Human Ecology 25(2):159-195. http://dx.doi.org/10.1023/ A:1021970021670

Scarlett, L. 2013. Collaborative adaptive management: challenges and opportunities. Ecology and Society 18(3):26. http://dx.doi. org/10.5751/es-05762-180326

Schoennagel, T., T. T. Veblen, and W. H. Romme. 2004. The interaction of fire, fuels, and climate across Rocky Mountain forests. BioScience 54(7):661-676. http://dx.doi.org/10.1641/0006-3568 (2004)054[0661:tioffa]2.0.co:2

Schwartz, M. D. 2013. Introduction. Pages 1-4 in M. D. Schwartz, editor. Phenology: an integrative environmental science. Second edition. Springer, London, UK.

Sefa Dei, G. J., B. L. Hall, and D. G. Rosenberg, editors. 2000. Indigenous knowledges in global contexts: multiple readings of our world. University of Toronto Press, Toronto, Ontario, Canada.

Senos, R., F. K. Lake, N. Turner, and D. Martinez. 2006. Traditional ecological knowledge and restoration practice. Pages 393-426 in D. Apostol and M. Sinclair, editors. Restoring the Pacific Northwest: the art of science of ecological restoration in Cascadia. Island, Washington, D.C., USA.

Shinneman, D. J., W. L. Baker, and P. Lyon. 2008. Ecological restoration needs derived from reference conditions for a semiarid landscape in Western Colorado, USA. Journal of Arid Environments 72:207-227. http://dx.doi.org/10.1016/j.jaridenv.2007.06.002

Sillitoe, P. 2002. Participant observation to participatory development: making anthropology work. Pages 1-23 in P. Sillitoe, A. Bicker, and J. Pottier, editors. Participating in development: approaches to indigenous knowledge. Routledge, London, UK.

Sillitoe, P., A. Bicker, and J. Pottier, editors. 2002. Participating in development: approaches to indigenous knowledge. Routledge, London, UK. http://dx.doi.org/10.4324/9780203428603

Sletto, B., and I. Rodriguez. 2013. Burning, fire prevention and landscape productions among the Pemon, Gran Sabana, Venezuela: toward an intercultural approach to wildland fire management in neotropical savannas. Journal of Environmental Management 115:155-166. http://dx.doi.org/10.1016/j. jenvman.2012.10.041

Smith, L. T. 1999. Decolonizing methodologies: research and indigenous peoples. University of Otago Press, New York, New York, USA.

Stankey, G. H., R. N. Clark, and B. T. Bormann. 2005. Adaptive management of natural resources: theory, concepts, and management institutions. General Technical Report PNWGTR-654. U.S. Department of Agriculture, Forest Service, Pacific Northwest Research Station, Portland, Oregon, USA. [online] URL: http://www.fs.fed.us/pnw/pubs/pnw gtr654.pdf
Stephens, S. L., and L. W. Ruth. 2005. Federal forest-fire policy in the United States. Ecological Applications 15(2):532-542. http:// dx.doi.org/10.1890/04-0545

Stephens, S. L., J. K. Agee, P. Z. Fulé, M. P. North, W. H. Romme, T. W. Swetnam, and M. G. Turner. 2013. Managing forests and fire in changing climates. Science 342:41-42. http://dx.doi. org/10.1126/science. 1240294

Stetler, K. M., T. J. Venn, and D. E. Calkin. 2010. The effects of wildfire and environmental amenities on property values in northwest Montana, USA. Ecological Economics 69:2233-2243. http://dx.doi.org/10.1016/j.ecolecon.2010.06.009

Stewart, O. C. 2002. Forgotten fires: Native Americans and the transient wilderness. University of Oklahoma Press, Norman, Oklahoma, USA.

Susskind, L., A. E. Camacho, and T. Schenk. 2012. A critical assessment of collaborative adaptive management in practice. Journal of Applied Ecology 49:47-51. http://dx.doi.org/10.1111/ j.1365-2664.2011.02070.x

Thorpe, N., S., Eyegetok, N. Hakongak, and the Kitikmeot Elders. Nowadays it is not the same: Inuit qaujimajatuqangit, climate and caribou in the Kitikmeot Region of Nunavut, Canada. Pages 201-240 in I. Krupnick and D. Jolly, editors. The earth is faster now: indigenous observations of Arctic environmental change. Arctic Research Consortium of the United States, Fairbanks, Alaska, USA.

Turner, N. J. 1999. "Time to burn:" Traditional use of fire to enhance resource production by Aboriginal peoples in British Columbia. Pages 185-218 in R. Boyd, editor. Indians, fire and the land in the Pacific Northwest. Oregon State University Press, Corvallis, Oregon, USA.

Turner, N. J., and H. Clifton. 2009. "It's so different today:" climate change and indigenous lifeways in British Columbia, Canada. Global Environmental Change 19:180-190. http://dx.doi. org/10.1016/j.gloenvcha.2009.01.005

Turner, N. J., and P. R. Spalding. 2013. "We might go back to this"; drawing on the past to meet the future in northwestern North American indigenous communities. Ecology and Society 18(4):29. http://dx.doi.org/10.5751/es-05981-180429

Turnhout, E., B. Bloomfield, M. Hulme, J. Vogel, and B. Wynne. 2012. Listen to the voices of experience. Nature 488:454-455. http://dx.doi.org/10.1038/488454a

Turpin, M., A. Ross, V. Dobson, and M. K. Turner. 2013. The spotted nightjar calls when dingo pups are born: ecological and social indicators in central Australia. Journal of Ethnobiology 33 (1):7-32. http://dx.doi.org/10.2993/0278-0771-33.1.7

United States Agency for International Development (USAID). 2005. Biodiversity conservation: a guide for USAID staff and partners. United States Agency for International Development, Washington, D.C., USA. [online] URL: http://webcache. googleusercontent.com/search?q=cache:2scl-usg $7 \mathrm{GoJ}:$ https://rmportal. net/library/content/tools/biodiversity-conservation-tools/usaidbiodiversity-guide-for-staff-parnters/view $+\& c d=2 \& h l=e n \& c t=c \operatorname{lnk} \& g \mathrm{l}=$ ca 
Venn, T. J., and D. E. Calkin. 2011. Accommodating non-market values in evaluation of wildfire management in the United States: challenges and opportunities. International Journal of Wildland Fire 20:327-339. http://dx.doi.org/10.1071/WF09095

Walther, G.-R., E. Post, P. Convey, A. Menzel, C. Parmesan, T. J. C. Beebee, J.-M. Fromentin, O. Hoegh-Guldberg, and F. Bairlein. 2002. Ecological responses to recent climate change. Nature 416(6879):389-395. http://dx.doi.org/10.1038/416389a

Warren, D. M., L. J. Slikkerveer, and D. Brokensha. 1995. Introduction. Pages xv-xviii in D. M. Warren, L. J. Slikkerveer, and D. Brokensha, editors. The cultural dimension of development. Intermediate Technology, London, UK.

Watson, A., L. M. Stumpff, and J. Meidinger. 2012. Traditional wisdom and climate change: contribution of wilderness stories to adaptation and survival. International Journal of Wilderness 18 (2):21-25.

White, R. 1999. Indian land use and environmental change: Island county, Washington: a case study. Pages 36-49 in R. Boyd, editor. Indians, fire and the land in the Pacific Northwest. Oregon State University Press, Corvallis, Oregon, USA.

Wildcat, D. R. 2009. Red alert! Saving the planet with indigenous knowledge. Fulcrum, Boulder, Colorado, USA.

Wildcat, D. R. 2013. Introduction: climate change and indigenous peoples of the USA. Climatic Change 120:509-515. http://dx.doi. org/10.1007/s10584-013-0849-6

Wilson, G. L. 1987. Buffalo Bird Woman's garden: the classic account of Hidatsa American Indian gardening techniques. Minnesota Historical Society, Minneapolis, Minnesota, USA.

Winter, G. J., C. Vogt, and J. S. Fried. 2002. Fuel treatments at the wildland-urban interface: common concerns in diverse regions. Journal of Forestry 100(1):15-21.

Wilcock, D. 2007. Examining 'inclusiveness' in adaptive natural resource management. Pages 455-460 in A. L. Wilson, R. L. Dehaan, R. J. Watts, K. J. Page, K. H. Bowmer, and A. Curtis, editors. Proceedings of the $5^{\text {th }}$ Australian stream management conference. Australian rivers: making a difference. Charles Sturt University, Thurgoona, New South Wales, Australia.

Williams, G. W. 2003. References on the American Indian use of fire in ecosystems. USDA Forest Service, Washington, D.C., USA. [online] URL: http://lakestatesfiresci.net/docs/AmericanIndianFireUse. pdf

Williams, J. 2013. Exploring the onset of high-impact mega-fires through a forest land management prism. Forest Ecology and Management 294:4-10. http://dx.doi.org/10.1016/j.foreco.2012.06.030

Williams, B. K., R. C. Szaro, and C. D. Shapiro. 2009. Adaptive management: the U.S. Department of the Interior technical guide. Adaptive Management Working Group, U.S. Department of the Interior, Washington, D.C., USA. [online] URL: http://www.usgs. gov/sdc/doc/DOI- $\% 20$ Adaptive $\% 20$ ManagementTechGuide.pdf
Woodward, E., S. Jackson, M. Finn, and P. M. McTaggart. 2012. Utilising indigenous seasonal knowledge to understand aquatic resource use and inform water resource management in northern Australia. Ecological Management and Restoration 13(1):58-64. http://dx.doi.org/10.1111/j.1442-8903.2011.00622.x

Ziervogel, G., and A. Opere, editors. 2010. Integrating meteorological and indigenous knowledge-based seasonal climate forecasts in the agricultural sector: lessons from participatory action research in sub-Saharan Africa. Climate change adaptation in Africa learning paper series. International Development Research Centre, Ottawa, Ontario, Canada. [online] URL: https://ipccwg2.gov/njlite download2.php?id=9382 